\title{
Morphological and molecular identification of Parabronema skrjabini of camels (Camelus dromedary) in Najaf province
}

\author{
H.H. Alfatlawy $\$ and M.A. Alfatlawi $\odot$ \\ Department of Veterinary Microbiology, College of Veterinary Medicine, University of Al-Qadisiyah, Al-Diwaniyah, Iraq
}

\begin{tabular}{l} 
Article information \\
\hline Article history: \\
Received May 12,2020 \\
Accepted June 07, 2020 \\
Available online June 23, 2021 \\
\hline Keywords: \\
Camelus dromedary \\
Parabronema skrjabini \\
Najaf \\
Iraq \\
\\
\hline Correspondence: \\
M.A. Alfatlawi \\
monyerr.abd@qu.edu.iq
\end{tabular}

\begin{abstract}
The current study was conducted during the period from September 2019 to December 2019, the number of examined samples 150 abomasums isolated from males 127 and females 23 to identify the species of Parabronema skrjabini that infected one-humped camel slaughtered in Al-Ashraf Najaf slaughterhouse. The microscopic examination of the worms was properties compared to other worms of the digestive system, and then confirmed using genetic markers with the polymerase chain reaction (PCR). Finally, the use of sequencing and phylogenetic analysis technologies relative to those that are predominant in world regions registered in the Gene bank. The results of the microscopic examination showed that Parabronema skrjabini distinguished by a red color, females are curved dorsally and longer than males with a vertically curved and head features that resemble a horseshoe for both sexes. The number of infected samples is $53(35.33 \%)$ and the noninfected samples $97(64.64 \%)$. The highest rate of infection during December month $63.41 \%$. On the other hand, the prevalence rate has been reported $65.21 \%$ females and $29.92 \%$ males with significant differences. In this research, PCR technique was used the molecular examination with the selection of the highest DNA samples, which were 10 samples to determine the alignment range according to the ITS2 gene, all samples were well suited to primer in length $783 \mathrm{bp}$ and confirmed the diagnosis of these nematodes.
\end{abstract}

DOI: 10.33899/ijvs.2020.127101.1459, (อ2021, College of Veterinary Medicine, University of Mosul.

This is an open access article under the CC BY 4.0 license (http://creativecommons.org/licenses/by/4.0/).

\section{Introduction}

Nematodes (roundworms) have cylindrical body (unsegmented) variable in color and size, the length from millimeters to centimeters and usually female longer than male (1). Parabronema skrjabini: one of the spirurida nematodes that infect abomasum of domesticated ruminants such as camel, cattle, sheep and goats. Baylis in 1921 was identified a genus Parabronema, first time described from Russia in 1924 by Rosawaska, this nematode was spread in different areas of the world as Mediterranean, Asia, central and east Africa (2). Most abomasal nematodes are caused diarrhea and lack of absorption, weakness, low weight and histopathological changes in abomasa mucosa lead to reducing the production or working efficiency of the infected animal and in case of blood-feeding nematodes may anemia and edema due to escape of plasma protein $(3,4)$. Parabronema skrjabini_is known with an indirect biological cycle, which require an intermediate host (flies) such as Stomoxy bengalensis, Paregle spp. and Lyperosia spp (5), after 1-2 days fly's egg are begin to hatching and feed on the contaminated dung. Finally, parasite's is penetrating the intestine wall of the flies by the anterior lancet (6-8). Ali et al. (9) diagnosed from camel's abomasum or form other host: goat. In small ruminants, Parabronema skrjabini is isolated from sheep in Al-Kut and recorded high prevalence rate of gastrointestinal nematodes during December $100 \%$, however less in March $44.47 \%$ (10). Parasite is firstly isolated from goats at Turky (11). Yagoob et al. (12) recorded $4.3 \%$ in sheep at baneh town/India. Most researchers in their studies were depended on microscopical examination of faeces and adult worms (4). Recent research was used molecular 
techniques to clarify the genotype of Parabronema skrjabini in many host (7-9). Different factors is affecting on the prevalence rate of abomasal worms (age, sex, climate and immunity status), the results of the study in Al-Kut, raq by Al-Dahar and Al-Amery (10) observed high prevalence of gastrointestinal nematode in sheep, females $75.37 \%$ males $66.5 \%$, because the adult sheep provided with high ability to resistance nematode's invasion compared to the young ages due to development of immunity response, on other hand the seasonal fluctuation associated with the activation of the intermediate host (6). Epidemiologial studies of abomasal nematods are documented an annual temperature during year, which play an important role of larval development or arrested $(9,11,12)$.

Arabian Camels (Camelus dromedaries) are important livestock animal live in harsh environments (13), the number of camels according to FAO, 2003 is around 12.5 million camels $70 \%$ of the world population (14). It's an increased the economic importance of camels with utilization of their products such as milk, wool, meat and skin $(3,15,16)$. Few studies have focused on intestinal worms in single-humped camels due to the difficulty of sampling and increased nomadic migration to remote areas (17). Al-Taif (18) was first study of one-humped camel's infection in Iraq. Few information is their prompted us to identify this nematode by morphologically distinguishing and sequence of its genotype.

\section{Materials and methods}

\section{The samples collection}

A total of 150 abomasum were directly collected from camel carcasses after slaughtering in Al-Najaf slaughterhouse. Data of animals were collected for the purpose of determining risk factors like sex, age, and time period. Transmission of samples in a cold box to the parasitology laboratory in the Veterinary Medicine College, Al-Qadisiyah University, the worms were isolated by forceps to diagnose the species of abomasal nematodes and depending on the diagnostic characteristics described by Soulsby (1). The worms placed on a glass slide and the clearing by a few drops of lacto phenol, and then soft pressure was applied to allow the body to lie flat without damage.

\section{Microscopically}

Macroscopical examination by using a light microscope to distinguishing the target nematode according to Ali et al. (4). The measurements of Prabronema were taken for morphological diagnosis (1).

\section{Extracted rDNA-ITS2 of Parabronema skrjabini}

The PCR technique and the extraction of rDNA depend on the package (gSYAN DNA Extraction / Gene aid / USA) was designed as a diagnostic marker for the presence of the
ITS2 gene (17). Primer pair were Para-Ir-F 5'- GTA GGT GAA CCT GCG GAAGG -3 and Para-Ir-R 5'- CTGAGC TGA GGT CAA CGA AT-3. In an automatic thermocycler, the overall volume of the PCR mixture was $100 \mu \mathrm{L}$, containing 1 standard buffer, $100 \mathrm{mMol} \mathrm{MgCl}_{2}, 100 \mu \mathrm{M}$ dNTP mix (AccuPowerTM PCR PreMix/Korea), 20 pmol of each primer, $1 \mathrm{U}$ Taq DNA polymerase (Cinaclone) and $1 \mu \mathrm{l}$ of DNA template (100 ng DNA). The PCR pathway was used the following protocol: first step $5 \mathrm{~min}$ incubation at $94^{\circ} \mathrm{C}$ to denature the double stranded DNA, 33 cycles at $94^{\circ} \mathrm{C}$ (denaturing), second step $45 \mathrm{~s}$ at $59^{\circ} \mathrm{C}$ (annealing), third step $45 \mathrm{~s}$ at $72^{\circ} \mathrm{C}$ (extension). Ultimately, the PCR was done at $72^{\circ} \mathrm{C}$ with 5 min extension stage. Agarose gel (1.5\%) prepared in using $1 \mathrm{X}$ TBE and dissolving in water bath at $100{ }^{\circ} \mathrm{C}$ for 15 minutes, after that, left to $\operatorname{cool} 50^{\circ} \mathrm{C}$, then $3 \mu 1$ of ethidium bromide stain were added into agarose gel solution. Agarose gel is poured into the tray after placing the comb in appropriate place after which, left to solidify at room temperature within 15 minutes, then removed the comb gently from the tray and inserted wells $10 \mu \mathrm{l}$ of PCR product and $5 \mathrm{ul}$ of (100bp Ladder) into one well. The gel tray was put in the electrophoresis chamber and filled in by $1 \mathrm{X}$ TBE buffer. the electric field was conducted for 1 hour at 100 volts and $80 \mathrm{gpm}$. Using UV Trans illuminator detection of positive bands.

\section{Statistics analysis}

The findings of this review have been analyzed using SPSS application to evaluate statistical differences with the Chi-square test $\left(x^{2}\right)$ and the $\mathrm{P}$ Values $\mathrm{P} \leq 0.05$ (19).

\section{Results}

\section{Microscopically}

The parasite is firmly embedding in the mucous layer of the camel's abomasa. Their mouth is provided with a pair of lateral psuedolabia and indicated in figures 1-4.

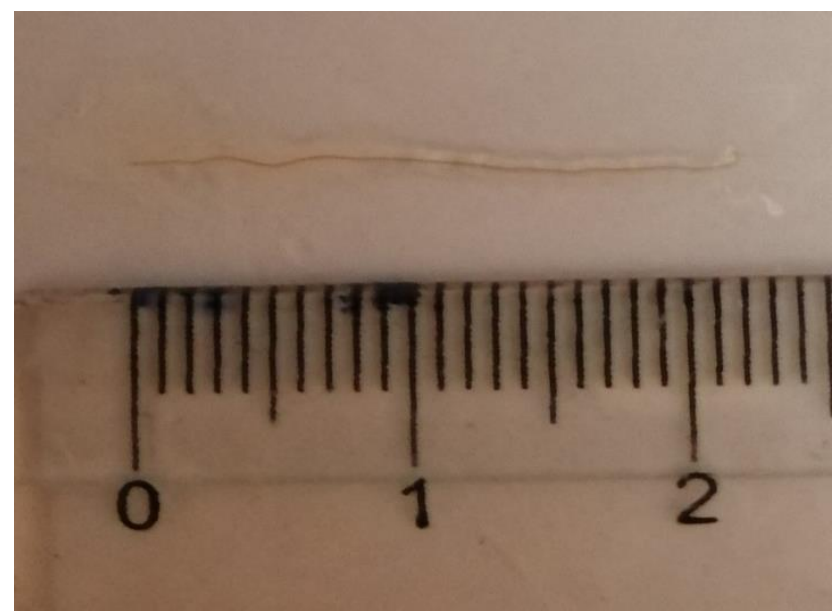

Figure 1: Adult female, 2.5x. 
Males

Body $26-30 \mathrm{~mm}$ in long, 104-119 $\mu \mathrm{m}$ in wide. Buccal cavity 90-110 (100) $\mu \mathrm{m}$ deep. The anterior section of the esophagus is $140-150(145) \mu \mathrm{m}$ and the posterior section is $1.52-1.70(1.61) \mathrm{mm}$ in long. No excretory pore has been observed, Tail is coiled ventrally, with some lateral alae at the posterior extremity. Spicules are distinctly unequal.

\section{Females}

Body $35 \mathrm{~mm}$ in long and $192 \mu \mathrm{m}$ in wide, unobserved pore excretory. Tail is pointed or blunt and distinctively curved on the dorsal side. Eggs with elongated form, anal opening $155 \mu \mathrm{m}$ from the posterior end.

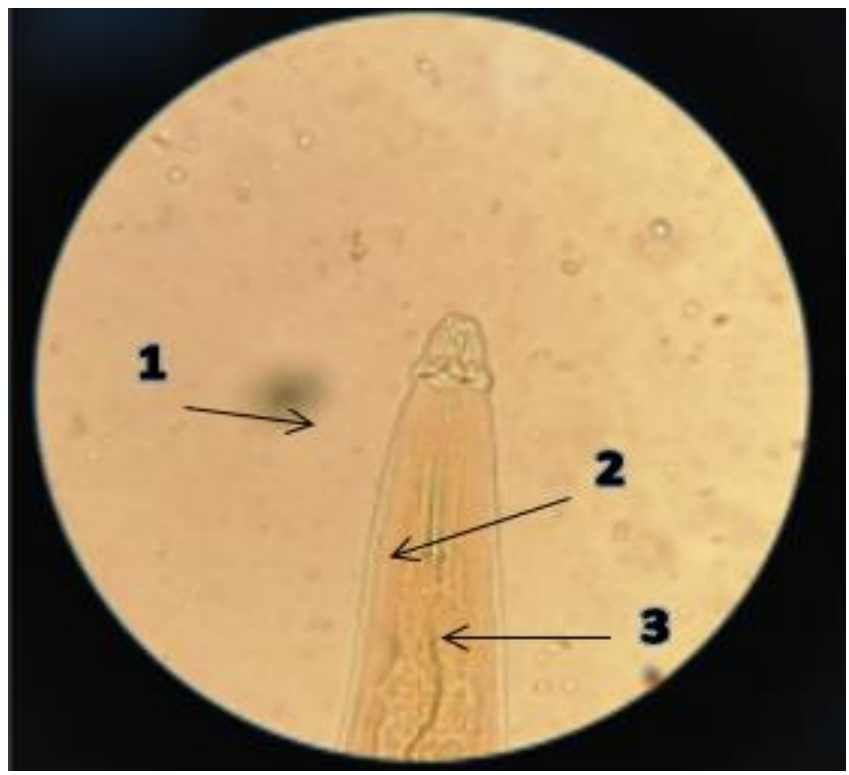

Figure 2: Anterior end (head) of parabronema skrjabini 1cuticular shields and cordons in the cephalic region 2Esophagus 3- Cuticle surrounds the body, 10c.

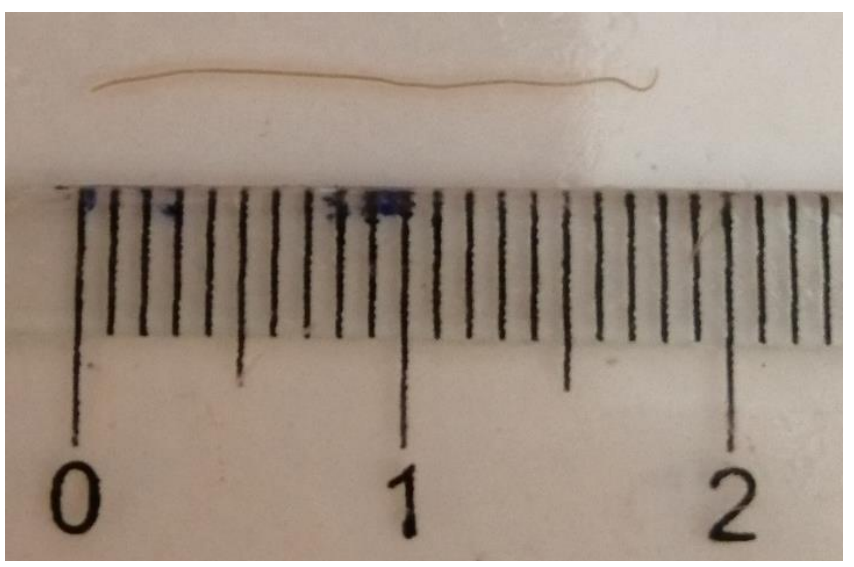

Figure 3: Adult male, 2.5x.

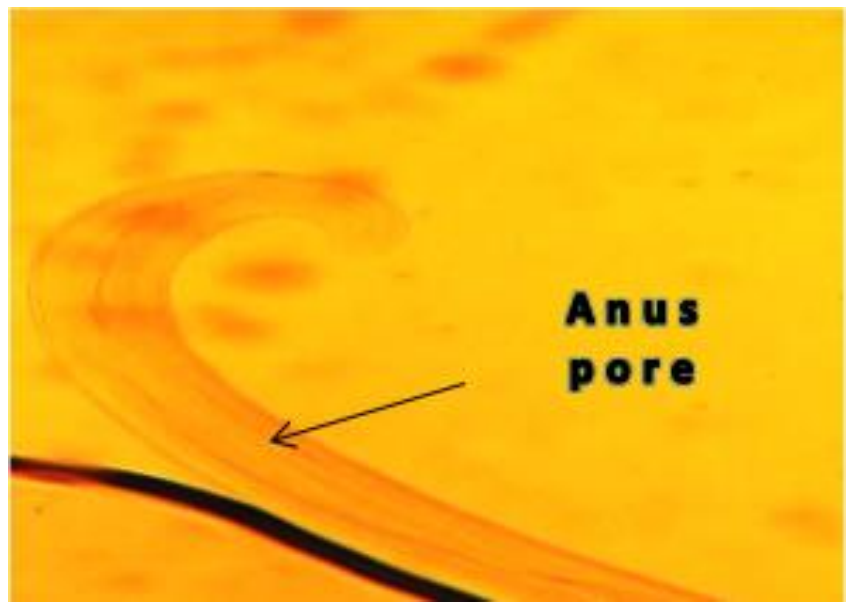

Figure 4: Posterior end of parabronema skrjabini (female), $10 x$.

\section{Infection rate of Parabronema skrjabini}

The results showed that among 150 camels, 53 positives for parasites with total infection rate $35.33 \%$. The highest rate in December were $63.41 \%$ while the lowest in September were $10(18.42 \%)$. Statistical analysis found that there were significant differences during study period of infection rates which showed in table 1.

Table 1: Infection rate of Parabronema skrjabini according to the study months

\begin{tabular}{lccc}
\hline Months & Exam No & Positive No & Percentage \% \\
\hline September & 38 & $7 \mathrm{a}$ & $18.42 \%$ \\
October & 28 & $9 \mathrm{~b}$ & $32.14 \%$ \\
November & 43 & $11 \mathrm{c}$ & $25.58 \%$ \\
December & 41 & $26 \mathrm{~d}$ & $63.41 \%$ \\
\hline Total & 150 & 53 & $35.33 \%$
\end{tabular}

The different letters show significant differences $(\mathrm{P} \leq 0.05)$.

The highest percentage of infection observed in 5 years group of age as $52.17 \%$ and the lowest rates were observed in age $\leq 2$ years $9.75 \%$, with significant differences as shown in the table 2 .

The results have shown that there are significant differences between males and females, females more affected by Parabronema skrjabini $65.21 \%$ than males $29.92 \%$ and referred into the table 3.

\section{Molecular Examination}

The ITS2-rDNA region of $P$. skrjabini, after amplifying and sequencing within ten samples, PCR amplicons were $783 \mathrm{bp}$ in the length, and showed in Figure 5. Lane (1-10) positive samples of $P$. Skrjabini isolates at 783bp. 
Iraqi Journal of Veterinary Sciences, Vol. 35, No. 3, 2021 (507-512)

Table 2: Infection rate of Parabronema skrjabini according to age

\begin{tabular}{lccccccccc}
\hline \multirow{2}{*}{ Months } & \multicolumn{3}{c}{ Camel $\leq 2$ year } & \multicolumn{3}{c}{$2-5$ year } & \multicolumn{3}{c}{ Camel $\geq 5$ year } \\
\cline { 2 - 10 } & Exam n & Infect n & Infect $\%$ & Exam n & Infect n & Infect \% & Exam n & Infect n & Infect \% \\
\hline September & 11 & 0 & $0 \%$ & 13 & 3 & $23.07 \%$ & 14 & $4 \mathrm{a}$ & $28.57 \%$ \\
October & 9 & $1 \mathrm{a}$ & $11.11 \%$ & 11 & 5 & $45.45 \%$ & 8 & 3 & $37.5 \%$ \\
November & 13 & 2 & $15.38 \%$ & 19 & $4 \mathrm{a}$ & $21.05 \%$ & 11 & 5 & $45.45 \%$ \\
December & 8 & 1 & $12.5 \%$ & 20 & $13 \mathrm{~b}$ & $65 \%$ & 13 & $12 \mathrm{~b}$ & $92.30 \%$ \\
\hline Total & 41 & 4 & $9.75 \%$ & 63 & 25 & $39.68 \%$ & 46 & 24 & $52.17 \%$ \\
\hline
\end{tabular}

$\overline{T h e}$ different letters show significant differences $(\mathrm{P} \leq 0.05)$.

Table 3: Infection rate of Parabronema skrjabini according to sex

\begin{tabular}{lcccccc}
\hline \multirow{2}{*}{ Months } & \multicolumn{3}{c}{ Male } & \multicolumn{3}{c}{ Female } \\
\cline { 2 - 7 } September & Exam No. & Infect No. & Infect \% & Exam No. & Infect No. & Infect \% \\
\cline { 2 - 7 } October & 31 & 3 & $9.6 \%$ & 7 & 4 & $57.14 \%$ \\
November & 25 & 8 & $32 \%$ & 3 & 1 & $33.33 \%$ \\
December & 38 & 8 & $21.05 \%$ & 5 & 3 & $60 \%$ \\
\hline Total & 33 & 19 & $57.57 \%$ & 8 & 7 & $87.5 \%$ \\
\hline
\end{tabular}

Significant differences at $(\mathrm{P} \leq 0.05)$.

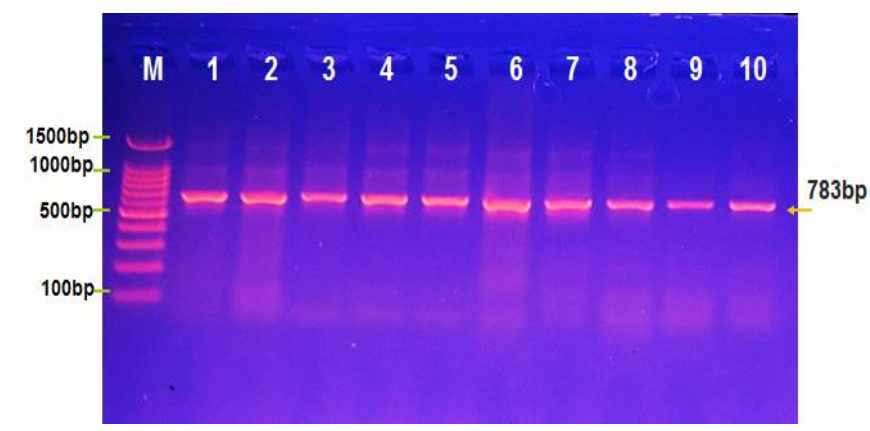

Figure 5: Electrophoresis image showed PCR product analysis ITS2-rDNA for $P$. Skrjabini Isolates from abomasum samples of one humped camel. Marker ladder 1500-100bp). Lane (1-10) positive P. Skrjabini isolates at $783 \mathrm{bp}$ product size.

\section{Discussion}

The present study shows Parabronema skrjabini in camels in Al-Najaf slaughterhouse, during the four months of the current study, the total infection rate is $35.33 \%$ the higher than the survey of Ali et al., (4) for the same location was $25.56 \%$ during the months of March, followed by January and February, with an emphasis on their research period (nine-months), suggesting they attribute the reasons for increased intermediate host (flies) prevalence in this time and the coinciding with temperature changes. Liu et al. in (20) recorded $86 \%$ higher in the Bactrian camel. The maximum infection reaches $81 \%$ and identical to the higher finding in the current study is $63.41 \%$ during the month of December. Some studies have been interesting in seasonal changes and their effect on infection rates during the year, where the seasonal prevalence of gastrointestinal nematodes in the Mashhad slaughterhouse / Khorasan province (15) had increased in certain seasons (summer and spring), Yakhchali (21) showed the climatic conditions are played an important role in infection rates, such as the spring and autumn seasons, researchers in Turkey have reported peak rates of parasites (11). El-Azazy (22) reported increased infections of small ruminants between December and October. Conversely, Borji et al. (15) confirming with his study of camel and other researchers for infection of small ruminants in Iran no they're indicating to a seasonal effect on the prevalence of nematode infection $(23,24)$, Barghandan et al. (25) after testing for sheep in three areas, the prevalence rates were similar for different seasons.

The results in the current study shows that females infection is higher than males in view of the small number of females slaughtered during the study time due to veterinary procedures in the Najaf slaughterhouse and the prevalence rate is $5652 \%$ females, $42.51 \%$ males and it was associated with the Iranian researchers of gastrointestinal camel nematodes with a P. skrjabini total infection rate of $34.7 \%$ and a higher female infection than male infection rate of $54 \%$ and $45 \%$ respectively (26). In small ruminants, the occurrence was $9.15 \%$ higher for females compared to 5.91 $\%$ males in sheep, and this difference in goats was not present at Basra city during P. skrjabini investigation (22). Hernández-Castellano et al. (27) assumed that the increase in ewes infection due to immune-modulatory responses was higher with parturition. Al-Dahar and Al-Amery (10) estimated the prevalence of $P$. skrjabini in sheep in December at a high rate of $100 \%$, with the variation in the 
incidence of infection between females and males in the province of Al-Kut, as the female was more affected by prolactin and its suppression of immunity, leading to an increase in the newly acquired larval fixation and their developing inside the animal.

On the other hand, other studies were rejected the relationship to some parasitic prevalence factors, as in Iran Hamadan, researchers observed the parasite infection by up to $22 \%$, but without affecting the sheep's gender (23), and this was identical to the results of other parasitologists during the study of abomasal nematodes in sheep at Baneh town $(12,25)$ no significant age, gender and season differences were observed. Al-Dahar and Al-Amery (10) suggested that infection rates in small ruminants have risen in young animals (1-2 years) due to repeated exposure to infection during grazing, this evidence was consistent with the other abomasal nematodes study in cows, which confirmed infections at 2-3 years of age (23).

The current study find that the seasonal fluctuations were influential and consistent with the results of the researchers looking for a disease in the camel $(4,6)$ or small ruminant $(9,11,28)$ by taking along with the difference in the number of samples and the period for the of their studies, which related to the spread of the intermediate host (flies). But, it did not agree with $(15,25)$ and the difference in results according to sex and age are consistent with the results in camel $(4,26)$ and small ruminant $(10,28)$, where females were more susceptible to nematodes as a result of lack of the examined numbers or immunosuppression, unlike what was suggested $(12,25)$. In the present study, the morphological results showed both male and female worms in infected camels, the length of the body was male $26-30 \mathrm{~mm}$ and female $35 \mathrm{~mm}$, horse shoe- shields in the cephalic region. The length of spicules is distinctly unequal and thus their similarity to the morphological characteristics with another studies $(4,7,22)$. The nuclear rDNA's first and/or ITS2 is suitable for diagnosis $(29,30)$. Some of the reports of Strongylida, Ascaridida, Dirofilaria, Dipetalonema and Thelazia (31-34) based on the gastrointestinal nematodes ITS regions. Molecular study of the genus Parabronema focuses mainly on the genes found in Genbank. The positive samples were similar to those reported were consistent with the molecular review of other hosts $(7,22,35-38)$.

The current data ensure the importance of the molecular techniques with morphological character in differentiating between Parabronema skrjabini and another species of nematodes that were identified for their presence in the abomasum of camels.

\section{Conclusion}

The current data ensure the importance of the molecular techniques with morphological character in differentiating between Parabronema skrjabini and another species of nematodes that were identified for their presence in the abomasum of camels.

\section{Acknowledgement}

I like to thank all workers in Parasitology Lab department of veterinary microbiology - college of veterinary medicine - Al-Qadisiyah University who has helped in carrying out the research.

\section{Conflict of interests}

The authors have not received any funding or benefits from industry, agency of financing, or elsewhere to conduct this study.

\section{References}

1. Soulsby EJL. Helminthes, Arthropods and Protozoa of Domesticated Animals. $7^{\text {th }}$ ed. England: Bailliere Tindall; 1982. 165 p. Doi: 10.1016/0035-9203(84)90110-X

2. Taylor M A, Coop RL and Wall RL. Veterinary Parasitology. $3^{\text {rd }}$ ed. Oxford: Blackwell Publishing. 2007; 311-318 p. DOI: 10.1002/9781119073680

3. Haroun EM, Mahmoud OM, Magzoub M, Hamid YA, Omer OH. The haematological and biochemical effects of the gastrointestinal nematodes prevalent in camels (Camelus dromedarius) in central Saudi Arabia. Vet Res Comm. 1996;20:255-264. Doi: 10.1007/BF00366923

4. Ali MJ, Alfatlawi MAA, Karawan AC. Molecular identification and phylogenetic-Tree analysis of Moniezia species from sheep in AlDiwaniyah city. Bulletin Iraq Na History Museum. 2018;15(2):131137. Doi: $10.26842 / \mathrm{binhm} .7 .2018 .15 .2 .0131$

5. Liu Y, Zhao Z, Yang X, Yang L, Yang B, Zheng W, Li W, Luo X, Wang R, Gu W, Wang P. Haematobium irritans and Haematobium titillans as potential vectors of Parabronema skrjabini in camels ( Camelus bactrianus) in Inner Mongolia, China. Parasitol. 2020;147(13):1509-1514. DOI: 10.1017/S0031182020001328

6. Seyed SH. Molecular characterization of the first internal transcribed spacer of rDNA of Parabronema skrjabini for the first time in sheep. Annals of Parasitol. 2015;61(4):241-246. DOI:10.17420/ap6104.13.

7. Hasheminasab SS, Jalousian F, Meshgi B. Molecular and morphological characterization of Parabronema skrjabini of sheep and goats at three different geographical zones in Iran. Annals Parasitol. 2016;62(1):2. DOI: 10.17420/ap6201.32

8. Al-Megrin WAI. Prevalence rate of intestinal parasites in camels in Riyadh, Saudi Arabia. Inter J Zool Res. 2015;11:65-70. DOI: $10.3923 /$ ijzr.2015.65.70

9. Ali A. Parasitological and molecular study of camel Anaplasmosis in Al-Najaf province, Iraq. Biochem Cellul Arch. 2019;19(2):3217-3222. DOI:10.35124/bca.2019.19.2.3217

10. Al-Dahar AHH, Al-Amery AMA. A prevalence of abomasal worms in sheep in Al-Kut province abattoir. Iraqi J Vet Med. 2015;39(2):38-41. DOI: 10.30539/iraqijvm.v39i2.175

11. Babjak M, Konigova A, Urda-Dolinska M, Varady M. Gastrointestinal helminth infections of dairy goats in Slovakia. Helminthol. 2017;54(3):211-217. DOI:10.1515/helm-2017-0027.

12. Yagoob G, Asso F. Assessment of abomasal nematodes in adult sheeps in Abattoir of Baneh Iran. J Biodiversity Environ Sci. 2014;4(4):106111. DOI: 10.3844/ajavssp.2013.142.145

13. Amin ASA, Abdoun KA, Abdelatif AmM. Seasonal Variation in Blood Constituents of One-humped Camel (Camelus dromedarius). Pakistan J Biological Sci. 2007;10(8):1250-1256. DOI: $10.3923 /$ pjbs.2007.1250.1256 
14. Al-Salihi K. Observations on dromedary Arabian camel and its diseases. MRVSA. 2011;5(1):1-10. DOI: 10.22428/mrvsa.23078073.2016.005SI1.X

15. Borji H, Razmi Gh, Movassaghi AR, Naghibi AGh, Maleki M. A study on gastrointestinal helminths of camels in Mashhad abattoir, Iran. Iranian J Vet Res. 2010:11(2):174-179. Doi: 10.22099/IJVR.2010.162

16. Khashkeli AA. A.Rreview on several important aspects of the camels. Aceh J Animal Sci. 2020;5(2):23-29. DOI: 10.13170/ajas.5.2.17580

17. Radfar MH, Gowhari MA. Common gastrointestinal parasites of indigenous camels (dromedarius) with traditional husbandry managements (free-ranging system) in central deserts of Iran. J Parasit Dis. 2013;37:225-230. DOI: 10.1007/s12639-012-0170-8

18. Al-taif KI. Helminths in camels in Iraq. Trop animal health and production. 1974;6(1): 55-57. DOI: 10.1007/BF02380750

19. Leech NL, Barrett KC, Morgan GA. IBM SPSS for Intermediate Statistics. $4^{\text {th }}$ ed. USA: Taylor and Francis Group; 2011. 210 p. DOI: 10.4324/9781410616739

20. Liu Y, Shi HL, Luo XP, Li JY, Wang R, Yang B, Wang PL, Zhai BT, Yang XY, Yang LR. Parabronema skrjabini (Nematoda: Habronematidae) infection and development in the intermediate hostHaematobia irritans (Linnaeus, 1758) in Inner Mongolia, China. Vet Parasitol. 2021;29(1):109326. DOI: 10.1016/j.vetpar.2020.109326

21. Yakhchali M. Study on parasitic helminths infection in gastrointestinal tract and respiratory system of sheep in Gilan Province, northern Iran. Vet ResSci Product. 2020;33(1):26-33. DOI: 10.22092/vj.2019.125386.1559

22. El-Azazy OME. Seasonal changes and inhibited development of the abomasal nematodes of sheep and goats in Saudi Arabia. Vet Parasitol. 1995;58(1-2):91-98. DOI: 10.1016/0304-4017(94)00696-a

23. Gharekhani J, Gerami SA, Yousefi M. Parasitic helminth infections in native sheep (Mehraban) in Hamedan, Iran. J Adva Vet Anim Res. 2015;2(2):115-119. DOI: 10.5455/javar.2015.b59

24. Kordi B, Mirzaei M, Nooshadokht M. Identification of abomasum nematodes fauna of ruminant in Kerman industrial Slaughterhouse, Iran. Studies. 2019;20(3):1-10. DOI: $10.26717 /$ BJSTR.2019.20.003441

25. Barghandan T, Hajialilo E, Sharifdini M, Javadi A. Prevalence and phylogenetic analysis of gastrointestinal helminths (Nematoda: Trichostrongylidae) in ruminant livestock of northwest Iran. Ankara Uni Vet. 2020;67(1):65-72:1-10. DOI: 10.33988/auvfd.588539

26. Sazmand A, Joachim A. Parasitic diseases of camels in Iran (19312017): A literature review. Parasite. 2017;24(1):21. DOI: 10.1051/parasite/2017024

27. Hernández-Castellano LE, Moreno-Indias I, Sánchez-Macías D, Morales-delaNuez A, Torres A, Argüello A, Castro N. Sheep and goats raised in mixed flocks have diverse immune status around parturition. J Dairy Sci. 2019;102(9):8478-8485. DOI: 10.3168/jds.2019-16731

28. Gasser RB, Newton SE. Genomic and genetic research on bursate nematodes: Significance, implications and prospects. Inter J Parasitol. 2000;30:509-534. DOI: 10.1016/S0020-7519(00)00021-7

29. Hasheminasab SS. Molecular characterization of the first internal transcribed spacer of rDNA of Parabronema skrjabini for the first time in sheep. Ann Parasitol. 2015;61:241-246. DOI: 10.17420/ap6104.13

30. Mar PH, Yang IC, Chang GN, Fei ACY. Specific polymerase chain reaction for differential diagnosis of Dirofilaria immitis and Dipetalonema reconditum using primers derived from internal transcribed spacer region 2 (ITS2). Vet Parasitol. 2002;106: 243-252. DOI: $10.1016 / \mathrm{s} 0304-4017(02) 00032-8$

31. Hung GC, Gasser R, Beveridge I, Chilton N. Species-specific amplification by PCR of ribosomal DNA from some equine strongyles. Parasitol. 1999;119: 69-80. DOI: 10.1017/s0031182099004497

32. Xq Z, Gasser RB. Single-strand conformation polymorphism (SSCP)based mutation scanning approaches to fingerprint sequence variation in ribosomal DNA of ascaridoid nematodes. Electrophoresis. 1998;19(8-9):1366-73. DOI: 10.1002/elps.1150190828

33. Otranto D, Tarsitano E, Traversa D, Giangaspero A, De Luca F, Puccini V. Differentiation among three species of bovine Thelazia (Nematoda:
Thelaziidae) by polymerase chain reaction-restriction fragment length polymorphism of the first internal transcribed spacer ITS-1 (rDNA). Inter J Parasitol. 2001;31:1693-1698. DOI: 10.1016/s00207519(01)00279-x

34. Mahmood MA, Essa MA. Antimicrobial activity of peptides extracted from camels' blood neutrophils against some pathogenic bacteria. Iraqi J Vet Sci. 2021;35(1):33-37. DOI: 10.33899/ijvs.2020.126239.1270

35. Ali MJ, Karawan AC, Al-Fetly DR, Alfatlawi MA. Synergizing the deltamethrin larvicidal activity against Aedes albopictus larvae using cinnamaldehyde in Diwaniyah, Iraq. Iraqi J Vet Sci. 2020;34(2):317320. DOI: $10.33899 /$ ijvs.2019.126026.1212

36. Alfatlawi MA, Ismail YK, Ali MJ, Karawan AC, Ibadi IN. Molecular differentiation of Thysaniezia (Helictometra) giardi and Moniezia species based on 18s rRNA gene in small ruminants. Iraqi $\mathrm{J}$ Vet Sci. 2021;35(1):105-108. DOI: 10.33899/ijvs.2020.126407.1313.

37. Alfatlawi MA, Jasim AJ, Jarad NE, Khlaif SF. Clinical and molecular identification of ruling Theileria annulata strains in cattle calves in AlDiwaniyah province, Iraq. Iraqi J Vet Sci. 2021;35(1):115-119. DOI: $10.33899 /$ ijvs.2020.126429.1319

38. Ahmed M, Singh N, Bera AK, Bhattacharya D. Molecular basis for identification of species/isolates of gastrointestinal nematode parasites. Asian Pacific J Trop Med. 2011;4(8):589-93. DOI: 10.1016/S19957645(11)60152-1

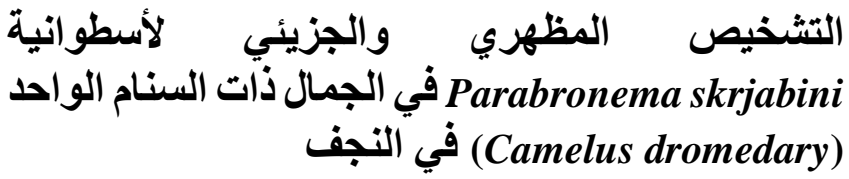

$$
\text { فيدر حمزة القتلاوي و منير عبد الأمير القتلاوي }
$$

الخلاصة

تم إجر اء الدر اسة الحالية خلال الفترة من أيلول 9 أب أب كانون الأول

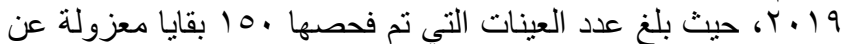

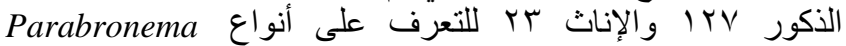
skrjabini

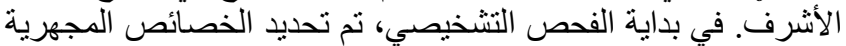
مقارنة بالديدان الأخرى في الجهاز الهضمي، ثم تم التأكيد عليها باستخدام

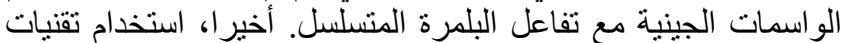
تحليل التسلسل والتطور النسبي بالنسبة لتلك السائدة في مناطق العالم التئل

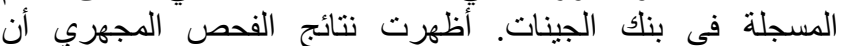
Parabronema skrjabini

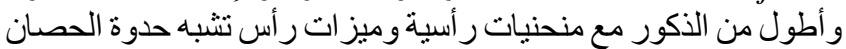

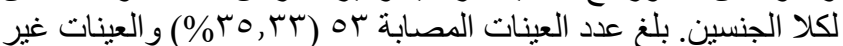

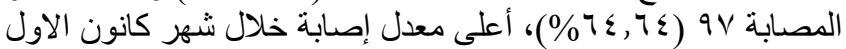

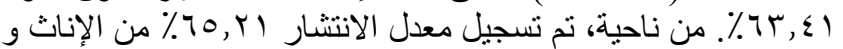

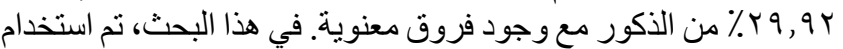

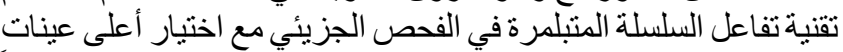

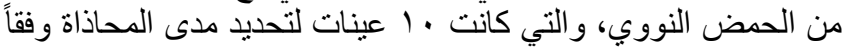

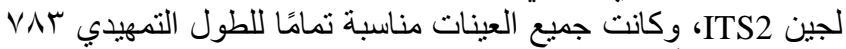
زوج قو اعد و أكدت تشخيص هذه الديدان الخيطية. 